\begin{tabular}{|c|c|c|}
\hline SALA & $\begin{array}{c}\text { Proceeding } \\
\text { International Conference on Islamic Educational Guidance and Counseling } \\
\text { 9 December 2021 } \\
\text { E-ISSN: 2827-9581 } \\
\text { Website: http://conference.iainsalatiga.ac.id/index.php/iciegc }\end{array}$ & $\begin{array}{l}\text { HEP } \\
\text { Hal. } 159-174\end{array}$ \\
\hline
\end{tabular}

\title{
DEVIASI SOSIAL HUBUNGAN SESAMA JENIS HOMOSEKSUAL PERSPEKTIF PSIKOLOGI ISLAM
}

Fitri Eliya $^{1}$, Putri Robiatul Ladawiyah ${ }^{2}$, Alfiah $^{3}$

UIN Suska Riau

\begin{tabular}{l}
\hline \hline Informasi Artikel \\
\hline Penulis Korespondensi: \\
Fitri Eliya, \\
Email: fitrieliya@gmail.com
\end{tabular}

\begin{abstract}
The term social deviation or more commonly referred to as deviation of behavior is a pattern of behavior that for many people this social deviation is a bad deed and exceeds the limits of the norms of propriety that can be tolerated by humans. Sexual orientation between men or gay sex is an example of behavioral deviations that clearly violate the norms of propriety in society and certainly do not conform to the teachings of any religion. exual relations between men or gay sex is an example of behavioral deviations that clearly violate the norms of propriety in society and certainly do not conform to the teachings of any religion. Studied in the view of Islam this perversion of sexual desire is clearly opposed to the creation of man by Allah SWT who must be in accordance with his codrad. The writing method used in studying maslah in the writing of this article is "library reseuarch" or literature research. The result of this study, namely deviant behavior in the form of male relationships with the same or homosexual is as a form of opposition to the human codrad that has been created by Allah SWT. Man must have high achievement in terms of the control of his passions is a way to train himself to have a high codrad that begins with the formation of noble morals. The attempt to be able to merubag akhlaq is to conquer anger, greed, and lust "shahwat". It is also an effort and a struggle of patience to build a habit. The despicable nature according to Imam Al Ghazali is a form of bathniah that if the despicable nature is erased then the praiseworthy nature will replace it.
\end{abstract}

Keyword: Social deviation; homosexuality; islamic physicology

\begin{tabular}{l}
\hline ABSTRAK \\
Istilah Devisiasi sosial atau yang lebih sering disebut sebagai \\
penyimpangan perilaku adalah sebuah pola prilaku yang bagi banyak \\
orang devisiasi sosial ini merupakan perbuatan buruk dan melampaui \\
batas norma kepatutan yang dapat ditolerir oleh manusia. Hubungan \\
seksual antara laki-laki sejenis atau homo seksual merupakan contoh \\
penyimpangan perilaku yang jelas melanggar norma kepatutan dalam \\
masyarakat dan pastinya tidak sesuai dengan ajaran agama manapun. \\
Dikaji dalam pandanga Islam penyimpangan hasrat seksualm ini jelas \\
menentang penciptaan manusia oleh Allah SWT yang harus sesuai \\
dengan kodradnya. Metode penulisan yang digunakan dalam \\
mengkaji maslah dalam penulisan artikel ini adalah "library \\
reseuarch" atau penelitian kepustakaan. Hasil dari penelitian ini, \\
yaitu perilaku menyimpang berupa hubungan laki-laki dengan sejenis
\end{tabular}




\begin{abstract}
atau homoseksual adalah sebagai bentuk penentangan terhadap kodrad manusia yang telah diciptakan oleh Allah SWT. Manusia harus memiliki pencapaian yang tinggi dalam hal pengendalia nafsunya adalah cara untuk melatih diri agar mempunyai kodrad yang tinggi yang dimulai dengan pembentukan akhlak mulia. Usaha untuk dapat merubag akhlaq adalah dengan menakhlukkan marah, ketamakan, dan nafsu "syahwat". Hal ini juga merupakan usaha dan perjuangan kesabaran untuk membangun sebuah kebiasaan. Sifat yang tercela menurut Imam Al Ghazali merupakan bentuk bathniah yang jika sifat tercela banyak terhapus maka sifat terpuji akan menggantikannya.
\end{abstract}

Kata kunci: Devisiasi sosial; homoseksual, psikologi islam

\title{
PENDAHULUAN
}

Manusia memiliki kecenderungan untuk mengerjakan tindakan-tindakan yang kurang terpuji, yang dikenal dengan istilah penyimpangan sosial "social deviance" atau patologi sosial yang dalam kajian sosiologi tampaknya sudah menjadi suatu sifat yang tidak dapat dipisahkan dari karateristik manusia. . Meskipun sebagai masyarakat mungkin kita mengetahui tentang "penyimpangan sosial, akan tetapi jika "penyimpangan sosial" ditandai dalam batas-batas tertentu, maka ketika itulah indikasi diberikan berbeda, contohnya penyimpangan perilaku yang tidak sesuai dengan standar norma dan sosial budaya yang berlaku didalam sebuah masyarakat.

Perilaku menyimpang adalah perilaku yang menurut banyak orang tercela dan di luar toleransi mereka. James W. Van Der Zanden (1993) menjelaskan bahwa deviasi dibagi dalam dua jenis, yaitu pertama deviasi primer (primary deviation) adalah jenis penyimpangan perilaku yang mana pelakunya masih dapat diterima masyarakat. Karakteristik penyimpangan ini adalah mempunyai sifat sementara atau temporer, dan tidak terus menerus, dan masih dapat dimaklumi oleh masyarakat. Yang kedua adalah penyimpangan sekunder (secondary deviation). Pelaku didominasi oleh perbuatan menyimpang karena merupakan pengulangan dari perbuatan menyimpang sebelumnya. Penyimpangan ini tidak dapat ditoleransi. Perilaku normal adalah perilaku yang sesuai (konsisten, tepat) yang dapat diterima oleh masyarakat luas atau oleh orang normal. yang relatif mendekati integrasi fisik-emosional yang ideal. Salah satu bentuk penyimpangan sosial yang telah menjadi fenomena masyarakat adalah isu perilaku seksual menyimpang dalam bentuk hubungan sesama jenis yang telah lama diperdebatkan. dalam peradaban manusia, kelompok yang merasa dirugikan oleh norma-norma tersebut. Perdebatan semacam ini semakin terlihat setelah munculnya kampanye oleh gerakan LGBT (Lesbian, Gay, Biseksual dan Transgender). 
LGBT mengakar di kehidupan Barat dan menjadi awal mula dari Gerakan LGBT. Gerakan ini mulai tumbuh pada tahun 1970 yang diawali dengan terbentuknya "Gay Liberation Front $(G L F)$ " di London dan menjadi cikal bakal dari gerakan LBGT pada masa kini. Dengan mengangkat isu hak asasi manusia, kaum LGBT merasa berhak untuk memilih orientasi seksualnya yang berbeda karena merupakan bentuk kemanusiaan. hak karena orientasi seksual yang menyimpang sudah ada dan terbentuk sejak kecil dan tidak dapat untuk disangkal.

Hal yang menjadi inspirasi terbentuknya Gerakan ini adala gerakan pembebasan di Amerika Serikat pada tahun 1969, yang berlangsung di Stonewall.2 Kampanye LGBT memiliki tujuan utama untuk menyadarkan kaum LGBT dan publik jika perbuatan mereka bukan hal yang menyimpang dan pantas untuk mendapatkan hak-hak seksual yang sama dengan manusia normal pada umumnya. Islam harus mengkaji secara serius mengenai fenomena LGBT sebagai bentuk perilaku penyimpangan sosial yang sangat fatal dan bertentangan dengan ajaran Islam. Tulisan ini akan membahas topik "Deviasi Sosial Hubungan Sesama Jenis Homoseksual Perspektif Psikologi Islam”.

\section{METODE}

Metode penelitian yang dipakai dalam penelitian ini adalah penelitian kepustakaan atau "Library Research" yang mengacu pada kajian teoritis dan referensi lain yang berkaitan dengan nilai, budaya dan norma yang dikembangkan dalam situasi sosial yang diteliti, data digali dari data, yang relevan dengan masalah yang dikaji untuk diteliti melalui studi literatur seperti buku, jurnal, artikel oleh peneliti terdahulu dan psikologi (Sugiyono, 2016).

\section{HASIL DAN BAHASAN}

\section{Teori Deviasi Sosial}

Penyimpangan sosial (behavioral social deviance) adalah segala bentuk perilaku yang tidak sesuai dengan norma sosial suatu kelompok sosial atau masyarakat, atau suatu perilaku yang melanggar ketentuan peraturan yang telah ditetapkan, yaitu peraturan yang telah disepakati secara benar dalam sebuah tatanan sosial. Penyimpangan perilaku sosial memiliki hakikat yang berbeda dalam pandangana masyarakat dan sudah pasti akan menimbulkan perbedaan pendapat diantara semua anggota masyarakat. Perbedaan itu dihasilkan dari perbuatan yang menentang aturan tertentu. 
Dalam Kamus Besar Bahasa, perilaku adalah tanggapan atau respon seseorang, yang di manifestasikan dalam bentuk gerakan (postur); bukan hanya tubuh atau bahasa. Penyimpangan memiliki kata dasar "simpang" yang berarti:

1. Sesuatu yang memisahkan (berbelok, bercabang, memutar, dsb) dari garis lurus;

2. Tempat belokan atau persimpangan, dari lurus (di tengah jalan). Arti dari penyimpangan adalah a) Berbelok untuk mengambil jalan yang berbeda atau menyimpang; b) Putar balik untuk menghindari tabrakan atau tabrakan (dari kendaraan, dll.), menghindar; c) Tidak seperti yang seharusnya, tidak sesuai rencana, dll; d) Menyalahi (kebiasaan, dll.); dan e) Menyimpang (dari hukum, dari kebenaran, dari agama, dll.).

Skinner (1994) membedakan perilaku menjadi perilaku bawaan "innate behaviour" dan perilaku operan "operant behaviour”. Untuk manusia, perilaku operant lebih dominan. bahagian besar dari perilaku ini adalah perilaku yang dibentuk dan dikendalikan oleh pusat kesadaran, yaitu otak (kognitif). Timbulnya perilaku yang dapat diamati merupakan hasil dari tiga kekuatan dalam diri individu, yaitu:

1. Kekuatan seseorang untuk cenderung mengulangi pengalaman yang menyenangkan dan untuk menghindari pengalaman yang tidak menyenangkan, disebut conditioning,

2. Kekuatan stimulasi atau stimulasi dari seseorang untuk ditindaklanjuti (teori stimulusrespon)

3. Kekuatan seseorang sudah ada di dalam dirinya.

Dapat disimpulkan bahwa perilaku menyimpang atau "social deviation" itu dilakukan secara sadar atau tidak sadar oleh seseorang. Perilaku menyimpang dapat dilakukan dimana saja dan oleh siapa saja. Penyimpangan yang dilakukan oleh individu atau sekelompok individu dapat mengganggu keseimbangan kehidupan dalam masyarakat. Menurut Jamez Van Der Zanden (dalam Akhidat, dkk., 2011), perilaku menyimpang merupakan perilaku yang paling sering dipandang tercela karena di luar toleransi. Robert MZ Lawang berpendapat perilaku menyimpang adalah suatu perbuatan yang berbelok dari kaidah noerma yang berlaku dalam sistem sosial dan memotivasi usaha dari pihak yang bertanggung jawab dalam sistem tersebut untuk memulihkan perilaku menyimpang tersebut. Berdasarkan jenis perilaku menyimpangnya, dibedakan menjadi dua bagian, yaitu: 1. Penyimpangan primer (primary deviation), yaitu penyimpangan yang dilakukan oleh individu tetapi pelakunya masih dapat diterima oleh masyarakat. Ciri-ciri penyimpangan 
ini bersifat sementara atau sementara, tidak akan terulang kembali, dan masih dapat ditoleransi oleh masyarakat. Misalnya tunggakan listrik, hipotek, dll.

2. Penyimpangan Sekunder (secondary deviation), yaitu penyimpangan berupa perbuatan yang dilakukan oleh seseorang yang biasa dikenal dengan perilaku menyimpang. Pelaku didominasi oleh perbuatan menyimpang. Karena itu merupakan pengulangan dari penyimpangan sebelumnya. Penyimpangan ini tidak dapat ditoleransi. dari masyarakat Misalnya pengguna narkoba, pembunuhan, prostitusi pelaku perampokan.

Perilaku menyimpang adalah perilaku yang tidak sesuai dengan aturan yang telah ditetapkan dalam kehidupan masyarakat setempat. Perbuatan menyimpang yang dilakukan melahirkan permasalahan bagi masyarakat dan dampaknya terhadap lingkungan. Menurut James W. Van Der Zanden (dalam Akhidat, dkk., 2011), faktor-faktor terjadinya perilaku sosial yang menyimpang ditimbulkan oleh:

1. Lemah atau tidak kuatnya nilai dan norma Ukuran perilaku menyimpang tidak didasarkan pada suatu ukuran baik atau buruk, benar, atau salah menurut pemahaman bersama, tetapi didasarkan pada ukuran lemah atau tidaknya norma dan nilai sosial dalam masyarakat lain.Di Indonesia, misalnya, berkumpul dipandang sebagai penyimpangan sosial, berbeda dengan masyarakat Barat, hidup bersama adalah hal yang wajar dan wajar.

2. Sosialisasi yang tidak sempurna, didalam kehidupan bermasyarakat kerap terjadi proses sosialisasi yang tidak sempurna yang menghadirkan perilaku menyimpang dalam masyarakat, misalnya: toleransi yang dimiliki masyarakat terhadap orang-orang yang terlambat membayar tagihan listriknya.

3. Penyebaran subkultur menyimpang, perilaku menyimpang yang ada pada orang-orang yang memiliki nilai subkultur menyimpang, yaitu budaya khusus yang normanya bertentangan dengan norma yang ada. Misalnya, di lingkungan kumuh tidak ada masalah etika dan estetika. banyak mendapat perhatian karena sibuk memenuhi kebutuhan pokok (pangan), sering berkelahi, mengucapkan kata-kata kotor dan lain-lain.

Perilaku menyimpang pada dirinya, menurut Casare Lamborso, ditimbulkan oleh beberapa faktor, yaitu:

1. Biologis, misalnya orang yang terlahir pencopet atau pembangkang, menjelaskan "penjahat terlahir" dari ciri-ciri tertentu yang dapat dimiliki manusia dari ciri fisiknya. seperti alis terjalin dapat diidentifikasi. 
2. Penjelasan psikologis bahwa penyebab penyimpangan itu ada hubungannya dengan kepribadian yang rusak atau kecenderungan untuk menyimpang.

3. Sosiolog menjelaskan bahwa penyebab perilaku menyimpang berkaitan dengan sosialisasi yang tidak tepat, individu tidak dapat menerima aturan.

4. Norma budaya yang menyimpang atau individu harus belajar untuk menyimpang dari norma budaya tersebut.

Dalam kaitannya dengan lingkungan sosial budaya ini, penyimpangan sosial ini dapat dibagi menjadi tiga bagian, yaitu:

1. Penyimpangan individu

Beberapa penyimpangan adalah gejala pribadi, pribadi atau individu karena disebabkan oleh karakteristik unik dari individu itu sendiri. hukum, kelainan), kelainan biologis dan kelainan jiwa tertentu yang diturunkan17 dan dibawa sejak lahir. Masalah perilaku juga dapat disebabkan oleh penyakit dan kecelakaan. Jika tidak ada diferensiasi biologis, penyimpangan ini pasti disebabkan oleh faktor sosial. dan pengaruh budaya. , yang membatasi dan memperburuk kualitas psikofisik individu. Penyimpangan semacam ini sering bersifat simtomatik, yang disebabkan oleh konflik intrapsikis yang kronis dan sangat dalam; atau itu berasal dari konflik yang diciptakan oleh identifikasi kontroversial yang saling bertentangan, konflik yang mengarah pada perpecahan pribadi.

2. Penyimpangan situasional

Penyimpangan jenis ini disebabkan oleh pengaruh berbagai kekuatan situasional/sosial di luar individu; atau menjadi bagian integral darinya melalui pengaruh situasi pada orang yang bersangkutan. Keadaan itu memberinya pengaruh yang memaksa, sehingga individu tersebut terpaksa melawan aturan-aturan umum atau melawan hukum biasa. Singkatnya, individu atau kelompok tertentu dapat mengembangkan perilaku yang menyimpang dari norma moral atau hukum sebagai akibat dari transformasi psikologis yang dipaksakan oleh situasi dan kondisi di lingkungan sosialnya.

3. Penyimpangan Sistematis

Penyimpangan Sistematis pada dasarnya adalah suatu subkultur atau sistem perilaku yang disertai oleh suatu organisasi sosial tertentu, status normal, peran, nilai, rasa bangga, norma dan moral tertentu, semuanya berbeda dari keadaan umum. Segala pikiran dan tindakan menyimpang kemudian dirasionalisasikan oleh semua anggota kelompok pola menyimpang, sehingga penyimpangan/penyimpangan perilaku menjadi penyimpangan yang terorganisir atau penyimpangan sistematis. 
Secara umum, kelompok pengalih ini memiliki peraturan yang sangat ketat, sanksi yang sangat ketat, dan undang-undang yang diperlukan untuk menegakkan ketaatan dan kepatuhan dari anggotanya.

\section{Psikologi Islam}

Psikologi Islam adalah pendekatan studi untuk memahami psikologi manusia dan perilaku manusia, yang didasarkan pada konsep tauhid, melalui integrasi pengetahuan dan keyakinan. Jangan biarkan hatimu percaya kepada Allah, tetapi bentuk atau pola pikirnya tidak mendukungnya. Sebagaimana diketahui, psikologi (sebagai disiplin ilmu) tidak diciptakan oleh umat Islam tetapi oleh orang Barat dan telah banyak memberikan kontribusi dalam segala bidang kehidupan dengan karyanya, meskipun cara berpikirnya sekuler. Pendapat Bastaman memberi definisi psikologi islami dengan corak psikologis islami dengan corak psikologi yang didasarkan pada citra manusia menurut ajaran Islam. Citra manusia menurut ajaran Islam, yang mempelajari singularitas dan pola perilaku manusia sebagai ekspresi pengalaman berinteraksi dengan diri sendiri, dengan lingkungan sekitar dan dengan alam spiritual, dengan tujuan meningkatkan kesehatan mental dan kualitas keragaman.Dalam psikologi Islam, nilai-nilai dasar Islam tentang kepribadian lebih banyak berhubungan dengan substansi manusia, yang terdiri dari substansi fisik berupa segala sesuatu yang material yang ada pada diri manusia, seperti tubuh manusia, anggota tubuh manusia, dan substansi terdiri dari nafsani yang didefinisikan oleh jiwa atau diri. Ketiga zat ini dapat dibedakan dengan jelas tetapi pasti tidak dapat dipisahkan. (Gumiadari, 2011)

\section{Penyimpangan Individual}

Penyimpangan individu adalah penyimpangan yang dilakukan oleh seseorang dalam bentuk penentangan terhadap norma budaya yang telah disepakati masyarakat. Penyimpangan muncul dikarenakan gangguan kejiwaan atau perbuatan tercela (pelanggaran) dan kriminal oleh seseorang. Yang termasuk dalam penyimpangan individu, yaitu:

1. Penyalahgunaan narkotika, adalah bentuk penyimpangan pada kaidah norma sosial dan agama

2. Prostitusi adalah perilaku menyimpang dengan melakukan hubungan seksual untuk mendapatkan imbalan.

3. Kejahatan seperti pencurian, penipuan, penyerangan, pembunuhan, perampokan dan pemerkosaan.

4. Penyimpangan gaya hidup seperti arogansi dan eksentrik. 
Penyimpangan seksual adalah perilaku seksual yang biasanya tidak dilakukan oleh seseorang Berbagai jenis penyimpangan seksual meliputi:

1. Lesbianisme dan homoseksualitas

2. Sodomi

3. Tranvrstitisisme

4. Sadisme

5. Pedofilia

6. Hubungan seksual diluar pernikahan

7. Tinggal besama tanpa ikatan pernikahan

\section{Definisi Hubungan Sesama Jenis (Gay)}

"Gay" adalah istilah yang umumnya digunakan untuk menggambarkan lelaki yang memiliki hasrat secara seksual kepada sesama laki-laki dan menampilkan sebuah kelompok yang kemudia berkembang di antara orang-orang dengan orientasi seksual yang serupa. Bell dan Weinberg mengklasifikasikan homoseksual ke dalam 5 jenis, yaitu :

1. "Close-couple Homoseksual" adalah pasangan homoseksual yang memiliki pasangan dan terlibat dalam aktivitas yang serupa dengan pernikahan heteroseksual. Tipe homoseksual memiliki lebih sedikit masalah, lebih sedikit pasangan seksual, dan frekuensi mencari pasangan seksual yang lebih rendah daripada tipe homoseksual lainnya.

2. "Open-couple Homoseksual" Jenis homoseksual ini memiliki pasangan dan hidup bersama, tetapi memiliki banyak pasangan seks dan menghabiskan lebih banyak waktu untuk mencari pasangan seks. Homoseksual ini memiliki lebih banyak masalah seksual daripada homoseksual dengan pasangan dekat.

3. Secara fungsional pasangan, dan mereka memiliki banyak pasangan seksual, tetapi dengan sedikit masalah seksual. Orang-orang homoseksual ini kebanyakan masih muda, belum menerima orientasi seksual mereka dan memiliki minat seksualitas yang tinggi.

4. "Disfungsional" Tidak ada pasangan tetap, memiliki banyak pasangan seksual dan banyak masalah seksual.

5. "Aseksual” Minat terhadap aktivitas seksual rendah pada kelompok ini dan cenderung menutupi orientasi seksualnya. Dari definisi di atas, penulis dapat menyimpulkan bahwa penyimpangan hasrat seksual seksual sesama jenis merupakam kejahatan cabul yang dilakukan oleh seseorang terhadap orang lain yang diketahui berjenis kelamin sama, seperti antara seorang wanita dan seorang wanita atau seorang pria dan seorang pria. . 


\section{Deviasi Sosial Hubungan Sejenis Homoseksual dalam Persfektif Psikologi Islam}

Berdasarkan persepsi psikologi islam adalah pemahaman pada manusia didasarkan pada ajaran islam. Terkait dengan hal ini psikologi harus dipersepsikan sebagai usaha dari manusia untuk mengungkap misteri Sunatullah yang bekerja dalam jiwa manusia (ayat Nafsani), dalam arti menemukan berbagai prinsip, unsur, proses, fungsi dan hukum tentang jiwa manusia (Djumhana, 2011) Ibnu Qayyim Aljauziyah menjelaskan bahwa Allah tergantung pada kebahagiaan seorang hamba dengan kemampuan hamba untuk menjaga kemaluannya, oleh karena itu tidak ada kebahagiaan bagi orang yang tidak menjaga kemaluannya (Aljauziyah, 2006). Hal ini sesuai dengan firman Allah SWT dalam Surrah Al-Mukminun ayat 1-7:

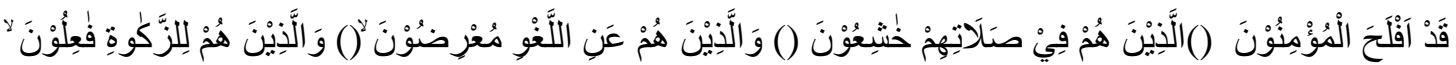

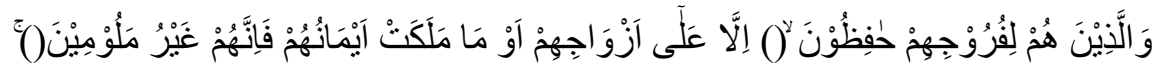

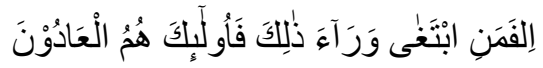

"Sungguh beruntung orang-orang yang beriman, (yaitu) orang yang khusyuk' dalam salatnya dan orang yang menjauhkan diri dari (perbuatan dan perkataan) yang tidak berguna dan orang yang menunaikan zakat dan orang yang memelihara kemaluannya. Kecuali terhadap istri-istri mereka atau hamba sahaya yang mereka miliki maka sesungguhnya mereka tidak terceIa. Tetapi barang siapa mencari di balik itu, maka mereka itulah orang-orang yang melampaui batas. Perbuatan sodomi yang dilakukan oleh para homoseksual dijadikan kategori perbuatan yang merupakan gabungan dari segala perbuatan keji. Akibat hubungan homoseksual tersebut dalam kondisi seluruh kerusakan yang disebabkan oleh perbuatan tersebut sudah tidak dapat dihitung lagi dan tidak ada yang mengetahui rinciannya kecuali Allah”. (QS-Almukminun: 1-7).

Homoseksual sebagai perilaku seksual menyimpang, bukanlah sebuah fenomena yang terjadi dimasa kini. Fenomena homoseksual sudah ada sejak zaman Nabi Luth yang dinamakan dengan kaum Sodom yang menyukai hubungan sesama jenis antara perempuan dengan perempuan (lesbi\}, dan lelaki dengan lelaki (homoseksual). Kaum Luth tidak menyukai hubungan yang dihalalkan Allah melalui pernikahan antara laki-laki dan perempuan. Sehingga diutuslah seorang malaikat untuk menyamar menjadi pemuda tampan yang bertamu ke rumah Nabi Luth dan diketahui oleh kaum Sodom sehingga yang mengundang nafsu para kaum Sodom kepada tamu Luth. Nabi Luth menawarkan putriputrinya untuk dinikahi sebagai ganti, tetapi kaum Sodom tetap menginginkan pemuda tampan yang menjadi tamu Nabi Luth. Hingga Luth berdoa "Ya Tuhanku, tolonglah aku (dengan menimpakan azab) atas kaum yang berbuat kerusakan itu”. Firman Allah SWT yang terdapat didalam Al-Quran Surrah AL-Ankabut ayat 29 dan 30, yang berbunyi: 
Homoseksualitas sebagai orientasi seksual menyimpang bukanlah fenomena yang baru terjadi dewasa ini. Fenomena kaum homoseksualitas sudah ada sejak zaman Nabi Luth, dinamai kaum sodomi yang memiliki ketertarika hubungan seksual sesama jenis antara wanita dan wanita (lesbian) dan laki-laki dengan laki-laki (homoseksual). Dia tidak menyukai hubungan yang diizinkan Tuhan melalui pernikahan antara seorang pria dan seorang wanita. Maka diutuslah seorang bidadari yang menyamar sebagai seorang pemuda tampan yang mengunjungi rumah nabi Luth dan dikenal oleh penduduk Sodom, untuk mengundang syahwat penduduk Sodom kepada tamu-tamu Luth. Nabi Luth menawarkan putrinya untuk menikah menggantikannya, para sodomi tetap menginginkan seorang pemuda tampan menjadi tamu Luth.Sampai Luth berdoa, "Ya Tuhanku, tolonglah aku (dengan menghukum orang) yang menyebabkan kerusakan." Firman Allah SWT terdapat dalam ayat 29 dan 30 dari Quran Surat Al-Ankabut yang mengatakan:

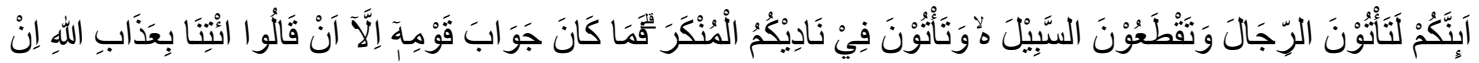

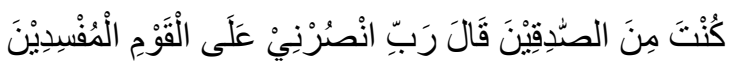

Dalam al-Qur'an ditemukan sejumlah ayat yang menjelaskan perihal siapa "kaum yang berbuat kerusakan itu”. Pertama, kaum Nabi Luth dengan perbuatan mereka yang begitu hina, yaitu menyukai berhubungan sesama jenis, seperti firman Allah, dalam surrah Qs Al-A'raaf Ayat 7-8, yang berbunyi:

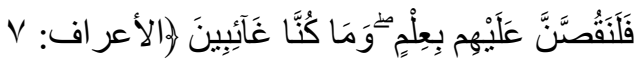

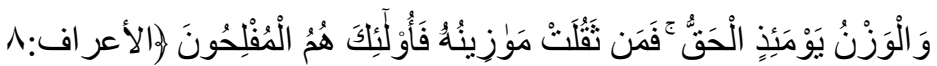

Artinya: "Dan (Kami juga telah mengutus Nabi) Luth (kepada kaumnya). (Ingatlah) tatkala dia berkata kepada mereka, "Mengapa kalian mengerjakan perbuatan yang sangat hina itu, yang belum pernah dilakukan oleh seorangpun (di dunia ini) sebelum kalian?"

Kaum Nabi Luth yang memiliki orientasi seksual menyimpang sesama jenis, dalam Surrah Arraf ayat 80, Allah Berfirman,

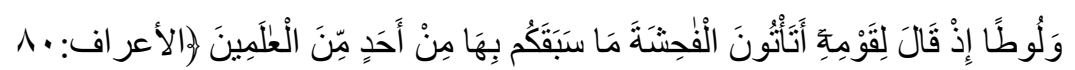

Artinya "Sesungguhnya kalian mendatangi lelaki untuk melepaskan nafsu kalian (kepada mereka), bukan kepada wanita, malah kalian ini adalah kaum yang melampaui batas" (QS. al-A'raaf/7: 81). 
Beberapa hadits menyebutkan, hal ini merupakan salah satu perbuatan "orang-orang yang mencelakakan”. Pertama: "Allah melaknat siapa saja yang menyukai perbuatan kaum Nabi Luth. Allah melaknat siapa saja yang bertingkah laku seperti perbuatan kaum Luth" Nabi Luth bersabda sampai tiga kali" (HR. Ahmad). Iman Tirmidzi menuliskn hadits Nabi Muhammad SAW: “Barangsiapa yang kamu temukan melakukan perbuatan kaum Nabi Luth, maka bunuhlah pelakunya dan pasangannya” Menurut penulis Tafsir Jalalain, Allah mengabulkan doa Nabi Luth. Allah SWT berfirman: "Dan tatkala utusan Kami (para malaikat) datang kepada Ibrahim membawa kabar gembira, mereka mengatakan, 'Sesungguhnya kami akan menghancurkan penduduk negeri (Sodom) ini. Sesungguhnya penduduknya adalah orang-orang yang zalim" (QS. al-Ankabut/29: 30). "Dan Kami turunkan kepada mereka hujan (batu) agar mereka melihat kesudahan orang-orang yang berbuat jahat” (QS. AlA'raaf/7:81). "Kemudian mereka dihancurkan oleh guruh yang nyaring ketika matahari terbit” (QS. AlHijr/15:73). Tidak hanya itu, Allah SWT berfirman dalam Surah Al-Hijr ayat 73:

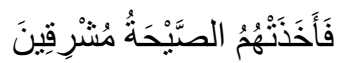

Artinya: "Maka Kami jadikan bagian atas kota itu terbalik ke bawah dan Kami hujani mereka dengan batu dari tanah yang keras" (QS. al-Hijr/15: 73).

Menurut Jalaluddin al-Suyuthi dan Jalaluddin al-Mahalli yang menyebabkan kota mereka terbalik ke bawah adalah karena malaikat telah mengangkatnya ke langit lalu menjatuhkannya dalam keadaan terbalik ke tanah. Sedangkan tanah yang keras itu adalah tanah liat yang dibakar dengan api. Inilah balasan untuk kaum Nabi Luth yang menantangnya Allah dengan tetap melakukan perbuatan hubungan sesame jenis yang dilaknat oleh Allah SWT.

Bagi Nabi Luth sendiri, yang membuat perih hatinya adalah isterinya termasuk yang mendapat azab dari Allah SWT. Istri Nabi Luth adalah yang memberi tahukan pada kaum Sodom bahwa ada tiga lelaki tampan berkunjung kerumahnya. Istri nabi luth mendapatkan azan Allah karena telah menghianati suaminya. Dalam Alquran Surrah Hud ayat 11 Allah berfirman:

Menurut Jalaluddin al-Suyuthi dan Jalaluddin al-Mahalli, kota mereka terbalik karena malaikat mengangkatnya ke langit dan kemudian menghempaskannya ke tanah Sedangkan tanah yang keras adalah tanah liat yang dibakar dengan api yang merupakan azab bagi kaum sodom terus melakukan hubungan sesama jenis yang dilaknat oleh Allah SWT. Bagi Nabi Luth sendiri, yang memilukan hatinya adalah istrinya termasuk orang yang mendapat azab 
dari Allah SWT. Istri Nabi Luth-lah yang memberi tahu para sodomi bahwa tiga pria tampan sedang mengunjungi rumahnya. Istri Nabi Luth menerima adzan karena berkhianat pada suaminya. Dalam Al Qur'an, Surat Hud, ayat 11, Allah berfirman:

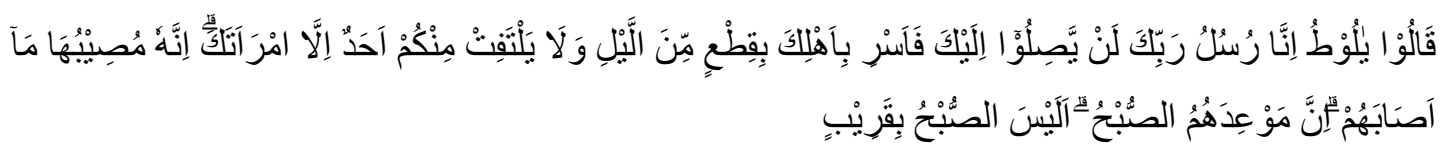

Artinya: "Para utusan (malaikat) berkata, 'Hai Luth, sesungguhnya kami adalah utusanutusan Tuhanmu, sekali-kali mereka tidak akan dapat mengganggu kamu, sebab itu pergilah dengan membawa keluarga dan pengikut-pengikut kamu di akhir malam dan janganlah ada seorangpun di antara kamu yang tertinggal, kecuali isterimu. Sesungguhnya dia akan ditimpa azab yang menimpa mereka karena sesungguhnya saat jatuhnya azab kepada mereka ialah di waktu subuh. Bbukankah subuh itu sudah dekat?” (QS. Hud: 81).

Dalam hadits Imam Thabrani, Nabi SAW bersabda: “Ada empat orang yang masuk di pagi hari murka dan murka Allah SWT di sore hari." Nabi SAW kemudian ditanya: "Siapakah mereka ya Rasulullah?” Nabi SAW menjawab: “(Pertama) Laki-laki meniru perempuan. (Kedua) Wanita meniru pria. (Ketiga) Orang yang berhubungan seks dengan binatang. (Keempat), seorang pria berhubungan seks dengan seorang pria. Syekh Nawawi Banten membahas hadits seperti ini dalam babnya sendiri yaitu "Fi Tasydid 'AlalLiwath" dalam kitab Tanqihul Qaul. Beginilah cara para pelaku lesbian, gay, biseksual dan transgender (LGBT) di negara kita dapat mengetahui betapa berbahayanya tindakan mereka. Hadits dari buku Tanqihul Qaul dikutip di sini. Nabi SAW bersabda: Allah SWT menyiksanya di neraka selama seribu tahun."Begitu pula Rasulullah SAW bersabda, "Jika pelanggar LGGT mandi dengan air laut, maka dia (masih) hidup dalam keadaan junub pada hari kiamat." Juga, jika seorang laki-laki berhubungan seks dengan laki-laki lain, maka keduanya sama-sama sah. Pezina."

Hal ini senada dengan sabda Nabi SAW: "Dan jika seorang wanita melakukan perbuatan lesbianisme dengan wanita lain, keduanya adalah pezina.” Nabi SAW bersabda, "Jika seorang pemuda menyentuh pemuda lain, maka singgasana itu menggoncangkan kami, perintahkan kami untuk menangkap mereka yang telah melakukan ini." Demikian juga bumi berbicara dengan lantang, "Ya Tuhan kami, perintahkan kami untuk menangkap mereka yang memakannya. mereka yang telah melakukan ini." Tentu saja sabda Nabi SAW di atas tidak bisa diabaikan begitu saja. , karena bisa jadi ketika Allah SWT murka terhadap pelaku LGBT maka seluruh bangsa Indonesia akan merasakannya. Apalagi di dalam al- 
Qur'an berkali-kali Allah SWT telah memperingatkan, "Dan datanglah kepadanya kaumnya dengan bergegas-gegas. Dan sejak dahulu mereka selalu melakukan perbuatanperbuatan yang keji. Luth berkata, 'Hai kaumku, inilah puteri-puteriku, mereka lebih suci bagimu, maka bertakwalah kepada Allah dan janganlah kamu mencemarkan (nama)ku terhadap tamuku ini. Tidak adakah di antaramu seorang yang berakal?” (QS. Hud/11: 78). "Mengapa kamu mendatangi jenis lelaki di antara manusia dan kamu tinggalkan isteriisteri yang dijadikan oleh Tuhanmu untukmu, bahkan kamu adalah orang-orang yang melampaui batas” (QS. al-Syu'ara/26:165-166).

Khusus untuk wanita yang membuat perilaku seksual yang menyimpang, ingat ayat ini "Allah membuat isteri Nuh dan isteri Luth sebagai perumpamaan bagi orang-orang kafir. Keduanya berada di bawah pengawasan dua orang hamba yang saleh di antara hamba-hamba Kami. Lalu kedua isteri itu berkhianat kepada suaminya (masing-masing), maka suaminya itu tiada dapat membantu mereka sedikitpun dari (siksa) Allah. Dan dikatakan (kepada keduanya), 'Masuklah ke dalam jahanam bersama orang-orang yang masuk (jahanam)' (QS. al-Tahrim: 66). Artinya menurut penulis Tafsir Jalalain, (masuklah ke dalam jahanam) "bersama orang-orang kafir dari kalangan kaum Nabi Nuh dan kaum Nabi Luth”.

Tindakan penyimpangan sosial dari hubungan sesama jenis antara laki-laki dan lakilaki atau homoseksual bertentangan dengan kodrat yang diciptakan Allah untuk manusia dan mereka merusak tatanan, dan Allah telah berfirman bahwa ini adalah tindakan yang berlebihan dan pelanggaran. : Siapa pun dia tidak bisa menjaga kemaluannya, jadi dia tidak termasuk orang yang beruntung dan bahkan termasuk orang yang hina, dia juga termasuk orang yang melampaui batas, kebahagiaan sudah berakhir, dia bahkan berhak disebut sebagai musuh Allah dan jatuh dari kasih karunia Rasa sakit nafsu seksual dan pengendaliannya jauh lebih mudah daripada menanggung semua penderitaan di atas (Aljauziyah, 2006).Imam Al Ghazali menjelaskan tentang sifat orang yang memiliki nafsu, yang terbagi menjadi tiga tingkatan jika dilihat dari ciri-cirinya, yaitu (Alghazali, 2017): Nafsu yang berada pada tingkatan yang paling rendah adalah nafsu amarah, yaitu , kesenangan, yang selalu memerintah. Jahat, nafsu Lawwamah, adalah jiwa yang selalu mengasihani dirinya sendiri, dalam keadaan ini tidak puas dengan kejahatan, sehingga cenderung dan tidak mampu mencapai ketenangan untuk menetap dalam kebaikan. Nafsu Allah dengan derajat yang paling tinggi adalah Nafsu Muthmainnah, suatu keadaan yang membedakan fitrah manusia dari semua binatang, nafsu yang murni dan dihiasi dengan 
dzikir kepada Allah, kemudian nafsu dihilangkan dari noda-noda nafsu yang tersucikan dan sifat-sifat yang tercela.

Hakikat fitrah manusia digambarkan dengan empat ciri komposit: yaitu, sab'iyyah (binatang buas), bahimiyyah (hewan ternak), syaithanyyah (setan), dan rabbaniyyah (keilahian). Ketika seseorang dikuasai oleh kemarahan, mereka telah menunjukkan perilaku binatang. seorang biadab Ketika dirasuki nafsu, ia telah melakukan perbuatan ternak.Sebagai hasil dari pemasangan kedua properti dalam seseorang dan penampilan cinta hurrat, kekejaman, kemurahan, makar dan penipuan, didominasi oleh sifat setan. Sebaliknya, jika jiwa seseorang berdiam pada hal-hal ketuhanan, maka ia akan menganggap bahwa ada hal-hal keilahian dan prioritas utama dalam dirinya. Ia mengendalikan dirinya dan tidak mau menuruti dirinya yang terbatas, yang justru sebaliknya. dengan tetap menjaga kesinambungannya bertujuan untuk mengatasi sifat-sifat yang tidak layak dilakukan dan mempertahankan sifat-sifat yang harus dipertahankan (Alghazali, 2017).

Melatih diri agar mempunyai fitrah terbaik dan pencapaian derajat nafsu tertinggi dimulai dengan pembentukan akhlak mulia. Upaya kami untuk mengubah moral berusaha untuk mengendalikan kemarahan, keserakahan, nafsu dan semua kualitas buruk yang ditunjukkan Syariah. Ini dihargai sebagai perjuangan usaha dan kesabaran untuk membentuk kebiasaan. Imam Al Ghazali menyatakan bahwa semakin banyak sifat tercela yang terhapus dari dalam diri manusia, maka banyak sifat terpuji yang akan menggantikannya (Alghazali, 2017). Dalam psikologi, istilah pengembangan pribadi dikenal sebagai metode pengembangan pribadi di mana persepsi, pengetahuan, keterampilan dan sikap meningkat, yang mencerminkan kedewasaan, untuk mencapai kondisi yang lebih baik. Hal ini harus didasarkan pada kenyataan bahwa manusia sebagai "the self-determined being" memiliki kemampuan untuk menentukan apa yang terbaik bagi dirinya guna mengubah nasibnya menjadi lebih baik. . pelatihan hidup" yang dikemukakan oleh Hanna Djumhana, yang menyatakan bahwa pengembangan kepribadian ini didasarkan pada prinsip "lima kesadaran”, yaitu (Djumhana, 2011):

1. Memahami akan citra diri yang diinginkan

2. Memahami akan diri sendiri kekuatan dan kelemahan

3. Memahami akan unsur pendukung dan hambatan di lingkungan

4. Memahami eprtimbangkan pendekatan dan metode pengembangan personal

5. Memahami tentang idola yang dijadikan contoh teladan 
Bagian dari upaya perubahan dan pengembangan pribadi ini kemudian akan mengarah pada upaya sistematis untuk menjadikan semua upaya yang menggabungkan aspek psikoterapi dan Islam sebagai bagian integral sebagai solusi untuk masalah homoseksual. kesehatan jiwa dapat dilihat pada Prof. Zakiah Darajat, yaitu (Djumhana, 2011):

1. Kesehatan jiwa adalah pencegahan terhadap gejala gangguan jiwa (neurosis) dan gejala penyakit jiwa (psikosis) pada manusia.

2. Kesehatan mental adalah kemampuan untuk menyesuaikan diri dengan diri sendiri, orang lain, dan dengan masyarakat dan lingkungan di mana seseorang tinggal.

3. Kesehatan jiwa adalah terwujudnya keselarasan sejati antara fungsi jiwa dan kemampuan menghadapi masalah bersama serta menghindari rasa takut dan konflik batin (konflik)

4. Kesehatan jiwa adalah pengetahuan dan tindakan yang ditujukan untuk mengembangkan dan menggunakan potensi, bakat, dan kualitas yang ada semaksimal mungkin untuk membahagiakan diri sendiri dan orang lain serta terhindar dari gangguan dan penyakit jiwa.

5. Kesehatan jiwa adalah tercapainya keselarasan sejati antara fungsi jiwa dan terciptanya penyesuaian diri antara manusia dengan dirinya dan lingkungannya, berdasarkan iman dan taqwa serta bertujuan untuk mencapai kehidupan yang bermakna dan bahagia di dunia dan sejahtera. Di dalam dunia. dari sekarang. bagian dari pencapaian kebahagiaan di akhirat, baik untuk diri sendiri maupun orang lain, dengan berusaha mengembangkan dan menggunakan potensi, bakat, dan kualitas yang ada semaksimal mungkin agar mampu menghadapi dan menghindari masalah yang biasanya muncul. Kecemasan dan konflik batin yang yang didasarkan pada iman dan takwa.

\section{KESIMPULAN}

Penyimpangan sosial (social deviation) adalah setiap perilaku yang tidak sesuai dengan norma sosial suatu kelompok sosial atau masyarakat. Perbuatan penyimpangan sosial, hubungan antara laki-laki sesama jenis atau homoseksual bertentangan dengan fitrah yang diciptakan Tuhan bagi manusia melatih jiwa untuk memiliki fitrah. Yang terbaik dan pencapaian tingkat nafsu tertinggi dimulai dengan pembentukan akhlak mulia. Upaya kami mengubah akhlak dengan berusaha menguasai amarah, keserakahan dan nafsu serta segala sifat buruk yang diperlihatkan syariat. Ini akan dibalas dengan perjuangan usaha dan kesabaran untuk membentuk kebiasaan." Imam Al Ghazali menjelaskan bahwa ketika 
banyak sifat tercela dihapus dari bentuk batin manusia, banyak sifat terpuji yang akan menggantikannya.

\section{DAFTAR RUJUKAN}

Ahmadi, A. (1997). Ilmu Sosial Dasar. Jakarta: Usaha Nasional.

Amiruddin \& Asikin, Z. (2004). Pengantar Metode Penelitian Hukum. Jakarta: PT. Raja Grafindo Persada.

Andina, E. (2016). Faktor Psikososial Dalam Interaksi Masyarakat Dengan Gerakan LGBT di Indonesia. Jurnal Masalah-Masalah Sosial, 7(2), 173-185.

Baharuddin. (2011). Aktualisasi Psikolog Islam. Yogyakarta: Pustaka Pelajar.

Djubaedah, N, (2010). Perzinaan Dalam Peraturan Perundang-Undangan di Indonesia ditinjau dari Hukum Islam. Jakarta: Kencana Prenada Media Group.

Gumiandari, S. (2011). Kepribadian Manusia Dalam Perspektif Psikologi Islam (Telaah Kritis Atas Psikologi Kepribadian Modern). (Unpublished Master's Thesis), IAIN Syekh Nurjati Cirebon, Cirebon, Indonesia.

Mohamed, Y. (2011). Fitrah and Its Bearing on the Principles of Psychology. American Journal of Islamic Social Science, 12(1), 1-18.

Philip \& Khan. (2003). Islam dan Homoseksual. Jakarta: Pustaka alZahra.

Shihab, M. Q. (2009) Tafsir al-Misbah, Jakarta: Lentera Hati.

Skinner. (1994). Human BehaviorThree levels of behavior. New York: Prentice-Hall Inc.

Soekanto, Soerjono, Sosiologi Penyimpangan, Jakarta, Rajawali, 1988.

Subandi. (2005) Reposisi Psikologi Islam, Yogyakarta: Temu Ilmu Nasional

Sunarto. (2004) Pengantar Sosiologi. Jakarta: Pranata Rahardja.

Surtiretna, N. (2000) Bimbingan Seks (Pandangan Islam dan Medis). Bandung: Rosdakarya.

Wardiana, U. (2004). Psikologi Umum. Jakarta: PT. Bina Ilmu. 